\title{
HENDERSON THE RAIN KING: THE HERO'S CROWNING AND DISCROWNING
}

\author{
Sigrid Renaux ${ }^{1}$
}

I

n former issues, several aspects of Saul Bellow's novel HENDERSON THE RAIN KING ${ }^{2}$ have already been discussed, such as space and time, the different aspects of Henderson's character, speech, his adventures with the Arnewi and part of his adventures with the Wariri, all of them inside Mikhail Bakhtin's concepts of the Menippean satire, polyphony and the carnivalization of literature.

! Universidade Federal do Paraná

2 Bellow, S. Henderson the Rain King. New York: Fawcett, 1959. All quotations from the novel are taken from this edition.

3 See Letras (39): 163-183, 1990; Estudos Anglo-Americanos (14-15): 104-132, 1990-91; Fragmenta (9), 1992; Estudos Anglo-Americanos (17), 1993; Humanas (2), 1993. This article corresponds to Chapter III, part 3, of my Ph. D. dissertation "Bellow's Camivalistic Vision of the World in Henderson the Rain King" (USP, 1978). The dissertation examines Bellow's novel by way of M. Bakhtin's Problems of Dostoevsky's Poetics, in which he discusses, among other aspects, the camivalization of literature, the Menippean satire and polyphony. In the Introduction, after reviewing the Ameriean criticism on the novel, a summary of Bakhtin's basic theories is presented, in order to show how Bellow is not only a follower but also an innovator of the Menippean satire and of camivalistic literature. Chapter I - The Land - deals with space and time in the novel, inside the Menippea's social utopia, showing how both can be placed on the levels of dream and reality simultaneously. Chapter II - The Hero - is concemed with the different aspects of Henderson's character which would place him inside the Menippea's moral-psychological experimentation. The hero's speech, in its turn, is examined by way of polyphony. Chapter III - The Quest - places the action of the novel inside 
In this issue, the climactic scene of the novel will be dealt with Henderson`s mock crowning and subsequent discrowning as Rain King or Sungo. Thus, if Bellow's hero has left America in order to flee his "curse" and gone to Africa in quest of truth and wisdom, and, with his loyal guide Romilayu, has already undergone two ordeals - the explosion of the frog cistern among the Amewi and raising the statue of Mummah, the cloud goddess, among the Wariri - he is now on the verge of being crowned the Wariris Rain King, as a consequence of having lifted the heavy wooden idol.

As Henderson tells us his adventures - as first-person narrator - after his feat of strength, "the Wariri jumped up and down in the white stone of their stands, screaming, singing, raving, hugging themselves and one another and praising me". The possibilities of rebirth and regeneration he had felt in America become true and he "welcomes life anew" in a carnivalistica joining of high and low words: "Damn the whole thing! Life anew! I was still alive and kicking and I had the old grun-tu-molani". His laughter of rebirth echoes while the Wariri continue "demonstrating in my honor, flaunting the flags and clattering rattles and ringing bells while they climbed over one another with joy" in a typical carnivalistic merriment.

The climax of the rain-marking festivities takes place now, for we have not only the mock-crowning of the king of camival in Henderson as the Sungo or Rain King, but also the whole pageant and ritual that goes with it: the high priest - the Bunam - brings leaves, wreaths, grasses and pines to the box where Henderson and Dahfu - the Wariri King - are, while two of the women carry skulls on long nusty standards and others hold small whips which resemble odd-looking fly whisks. In this manner, the camival category of eccentricity - using household utensils as weapons - appears together with symbols of fertility and death, as befits carnival symbols. They all wait for Henderson, who only faintly suspects a new ordeal is awaiting him, while Dahfu, the black leather man, the Bunam and the rest of them are scrutinizing him with their black eyes.

the most imponant of the Menippean characteristics, the creation of extraordinary situations to provoke and test a philosophical idea: the word or the truth. These extraordinany situations are in their tum imbued with a whole series of camivalistic categories, rituals and images, making ambiguous any monological interpretation of the novel. In the Conclusion we show how all aspects of the novel are brought together and how the work acquires a much richer and complex perspective, if examined through the camivalistic vision of the world, which Bellow has conveyed to us. 
Henderson's imminent crowning as rain king has again all the characteristics of the mock crowning of carnival, as expressed by the brevity of this position. As Dahfu explains to him, after conferring on him the title of Sungo,

"Now, Mr. Henderson. We have news for you. The man who moves Mummah occupies, in consequence, a position of rain king of the Wariri. The title of this post is the Sungo. You are now the Sungo, Mr. Henderson, and that is why they are here".

Dahfu also adds "Today you are the Sungo".

As Henderson's fears increase, the king soothes him by explaining that "they require your attendance to cleanse ponds and wells. They say you were sent for this purpose". Henderson is then stripped of his garments and the Sungo's outfit is put on him, according to the carnival ritual of changing of clothing, and with it, of positions and destinies in life: ${ }^{4}$

The examiner came up from behind and lifted off my helmet, while the stiff and stout old generaless, bending with some trouble, removed my shoes. And after this, useless to resist, she took off my Bermuda shorts. This left me in my jockey underpants. which were notably travel-stained. Nor was that the end, for as the Bunam dressed me in the vines and leaves, the generaless began to strip me of even the last covering of cotton "No, no," I said, but by that time the underpants were already down around my knees. The worst had happened, and I was naked. (...) I tried to shield my nakedness with hands and leaves, but Tatu, the amazon generaless, pulled away my fingers and put one of those many-tongued whips into them.

Like Dionysus, as carnival king, Henderson is dressed up in vines and leaves as the Wariri Rain King, with even a scepter in his hands, in his green splendor as Sungo, while everybody yells "Sungo, Sungo, Sungolay". And, if the white color of the calcareous stone paving the arena conveys sterility, the green color which Henderson is dressed in as Sungo, in contrast, conveys the fertility of spring and rain rituals symbolized in the leaves, wreaths, grasses and pines with which the Bunam covers him. Moreover, the comicality of the whole scene - in which carnivalistic disguise mixes 
with the menippea's "underworld naturalism", free gestures, oxymoronic combinations - reflects the mocking nature of the whole crowning scene, in which a "slave"becomes "King". This is a typical camival complex - a crowd of masqueraders, a farcical crowning, comedy and tragedy, a king that is a clown.

Then they all start to run, thus performing another carnival gesture, entering the crooked lanes of the town. Henderson "s next "ordeal" has begun, for with his "feet lacerated by the stones, dazed, running with terror in my bowels" he still is the rain king. Amidst the naked amazons chanting and crying, Henderson "was dancing on burnt and cut feet over hot stones. I had to yell, too. Instructed by the generaless, Tatu, who brought her face near mine with open mouth, shrieking, I too cried, 'Ya-na-bu-ni-ho-no-mummah!" In the middle of this rebirth or crowning ceremony, Henderson accompanies not only the dancing, but also the yelling and thus he becomes again the Dionysiac hero. In Wylie Sypher`s words

when he sings the wild songs of Bacchus, man loses his personal identity, his "differentiation," and ceases to be a thinker. He becomes the Dionysiac hero, the archetypal Reveller. In the epidemic theatre there is a metamorphosis, for civilized man finds again his archaic being among the throng.

Carnival excesses follow this crying, thus mixing magic words with grotesque symbols of life and death, youth and age, high and low, the crowd nunning harder now, forming a crescendo of life out of its "usual nut":

A few stray men, mostly old who happened to be in the way were beaten by the women and scrambled for their lives, and I myself hopping naked in the flimsy leaves appeared to strike terror into these stragglers. The skulls on the iron standards were carricd along as we ran. They were fixed on sconces. We made a circle of the town way out as far as the gallows. Those were dead men that hung there, each enteraining a crowd of viltures. I passed beneath the swinging heads, having no time to look, for we were running hard now, a hard course: panting and sobbing, I was, and saying to myself, Where the hell are we going?

5 Sypher, W. The Meanings of Comedy, In: Comedy. New York: Doubleday, 1956. p. 224. 
The oxymoronic combination between this carnivalistic scene of Henderson running and dancing among the Wariri, and the swinging of the dead corpses on the gallows brings us back again to the core of carnival symbols, in which birth (the rain-making ceremonies, in which nature renews itself) is fraught with death (the executions that had taken place the day before) and death with new birth.

Their destination is the big cattle pond where a comic rebirth ceremony or baptism takes place, for, still leaping and chanting, the women

threw themselves upon me. They picked me up and gave me a heave that landed me in the super-heated sour water in which some long-horned cattle were standing. This water was only about six inches deep; the soft mud was far deeper, and into this I sank I thought they might mean me to lie there sucked into the bottom of the pond, but now the skull carriers offered me their iron standards, and I latched on to these and was drawn forth. I might almost have preferred to remain there in the mud, so low was my will. Anger was useless. Nor was any humor intended. All was done in the greatest earnestness. I came, dripping stale mud, out of the pond.

This contact with water and mud brings us back to Henderson's experience with the Arnewi, where water and mud had been disagreeable experiences, with negative implications, for they meant disaster for Henderson and the natives, with the dead frogs offering a sickening sight in the yellow mud at the bottom of the reservoir. Here, however, Henderson's second experience with water - his elemental enemy, as he is a compound of fire and earth characteristics - and mud is far more positive, for, according to Bachelard, mud has "des valeurs anciennes":

les bains be boue garderaient encore (...) les hormones des pollens antédiluviens! Être ainsi guéri par les fleurs d'autrefois, réanimé par les printemps disparus, c'est, au moins par l'éfficacité des rêves, une grande vérité. 6

If water/mud in the first experience has been a negative element (the dead frogs covered with mud reflecting back the image of the octopus filling Henderson with "cosmic coldness" making him feel he was "dying") we now

6 Bachelard, G. La Terre et les Réveries de la Volonté. Paris: J. Corti, 1971. p. 132. 
move to more positive results in which mud, as "soft matter", in the cattle pond, rejuvenates Henderson with its "hormones of antidiluvian polens". Water is here not only related to earth through mud, but also to fire, for the pond is "superheated". And Henderson's "bain de boue" is a comic counterpart of Bachelard's quotation, for as rain and fertility king - as he later discovers - he is also reanimated by the lost springtimes and ancient flowers: mud has led Henderson back to the "valeurs anciennes", in the same way that he has found in Africa "the ancient bed of mankind". Because of this, his experiences with the natives tend to be primitive, ancient, ritualistic. Henderson's "old self" thus "dies" and is "reborn"through these experiences - like Dionysus, who has the power to die and come to life again - through pain and ordeal (as later on he will also "die" in Dahfu and be "reborn" in the king's blood, as his successor and mental inheritor). And, if he was discrowned after his first experience with the Arnewi, now he remains the Wariri rain king, with all the comic overtones this implies, in a carnivalistic atmosphere. The death-rebirth theme, as always, crosses Henderson's path, this time through his unexpected mud bath.

The earnestness with which the Wariri perform this business of throwing Henderson into the cattle pond is set in contrast again to his parodical description of his own position when he ennumerates his titles and characteristics, once more in an oxymoronic combination of high and low:

Yes, here he is, the mover of Mummah, the champion, the Sungo. Here comes Henderson of the U.S.A. - Captain Henderson, Purple Heart, veteran of North Africa, Sicily, Monte Cassino, etc; a giant shadow, a man of flesh and blood, a restless secker, pitiful and rude, a stubbom old lush with broken bridgework, threatening death and suicide.

The exhilaration produced by wine and Dionysus' ecstatic worship, characterized by wild dances, thrilling music and tipsy excess ${ }^{7}$ becomes again manifested in the exceses of the rainmaking ceremonies, where Henderson in his Dionysian outfit runs, against his will, back towards the arena. As in the ceremonies of the Dionysian cult of suffering and resurrection of the god, Henderson undergoes an ordeal that leads up to his "death" and "resurrection" with the coming of rain, for, surrounded by whips, skulls and guns, Henderson 
was whirled with them, their rain king, crying in my filth and frenzy, "Ya-na-bu-ni-ho-no-mum-mah!" as before (...) O, you rulers of heaven! Oh, you dooming powers! Oh, I will black out! (...) We were yelling and jumping and whirling through terrified lanes, feet pounding, drums and skulls keeping pace (...) After the gust of breeze came deeper darkness (...) we all turned and rushed into the arena - I with the rest, spinning around inspired, (...). There was great delirium. They were shricking, shricking (...). All were flying toward me, entering my brain (...). The women about me were dancing (...). They were hounding and screaming and banging their bodies into me.

This quotation again brings out other similarities between the rites of Dionysus adn Henderson's crowning ceremony, fot the singing and shrieking of the natives acquire dythirambic overtones - those Greek choric hymns of wild character - while the whole ceremony acquires a Bacchanalian atmosphere. For both the Dionysian rites and the rain-making lestivities have again the same bjective of celebrating fertility through the life cycle of the seasons: birth, growth, decay, death, and rebirth. The lamentation of the Amewi because of drought and the revelry and rejoicing of the Wariri after Henderson has moved Mummah and thus bought rain, again in an oxymoronic combination, attest to its power of regeneration. In a larger context, the life cycle of seasons has the same structure as comedy, for, as W. Sypher points out,

from the anthropologist's view (...) the entire ceremonial cycle is birth: struggle: death: resurrection. The tragic are is only birth: struggle: death. Consequently the range of comedy is wider than the tragic range (...) and comic action can risk a different son of purgation and triumph."

This view helps us to better understand the whole conception not only of the rain-making festivities, to produce fertility through rain, but also of the whole novel. 
Henderson then, dripping stale mud, cries out to heaven and to the dooming powers, as his ordeal continues and he is whirled on among the naked natives, in an invocation to the supernatural powers: ${ }^{9}$

"Mercy, have mercy!" And after that I yelled, "No, justice!" And after that I changed my mind and cried, "No, no, truth, truth!".

It is the climactic cry for truth in the hero's extraordinary situation, thus exemplifying again the Menippean characteristic of the search for truth, as also the camivalistic two-in-one images, uniting the high and the low, for Henderson is a king but also a "restless seeker", a "pitiful rude man", a "poor stumbling bully", a captain but also "a stubbom old lush (...) threatening death and suicide". The ordeal is still not over, for while the yelling and jumping goes on through "terrilied lanes, feet pounding, drums and skulls kecping pace", the sky slowly lills with heavy rain clouds and the air becomes "tumescent, heavy", yearning for a "discharge". Fire imagery, in contrast to the oncoming rain, is again present in this orgiastic scene, for Henderson, is his comic earth costume, "felt like Vesuvius, all the upper part flame and the blood banging upward like the pitch or magma".

The deeper darkeness ${ }^{10}$ that approaches is again compared to "the pungent heat of the trains when they pass into Grand Central tunnel on a devastated day of August, which is like darkness eternal" thus mingling in one extended fire image the scorching heat outside in nature and inside Henderson's body and feelings.

Henderson then runs back to the arena with the amazons, while the people are "standing, leaping, frantic, under the oppression of Mummah's great clouds, those colossal tuberous forms almost breaking". In a tremen-

9 As E.Rohde describes the Dimysian "state": "Diese Onerreizung der Emplindung his $z$ v visionären Zuständen bewirkten, bei hiefür Empfängliche, der rasende Tan/wirhel, die Musik, das Dunkel, all die Veranstaltungen dieses Aufregungskultes. Diese äusiersle Erregung war der Zweck den man erreichen wollte. Einen religiösen Sinn hatte diese gewaltsan herbeigeführe Steigerung des Gefühls darin, dass nur durch solche Oherspannung und Ausweitung seines Wesens der Mensch in Vertindung und Berührung treten a kinnen schien mit Wesen einer höheren Ordnung. mit dem Gotte und scinen Geisterscharen". Psyche. Leiprig: Kröner, 1893. p. 146-7.

11 Darkness seems to acyuire a deeper significance in a similar passage in the Achentures of Augie Manch, in which the darkness covering Westminster is one "in which resolutions have to he made - it isn"t merely local; it s the same darkness that exists in the fiercest cleamesies of torrid Messina". New York: Viking. 1969. p. 201. Nevertheless, the implications: seem to he similar. 
dous delirium, they are nearing the gods, and the women rush upon the figures of the gods and strike them violently with their whips, in spite of Henderson's yells, while the gods "bore it defenseless". Henderson throws himself down, trying with all his might to avoid beating the gods himself, but Tatu raises him to his kness, and in this humiliating or "discrowning" position, crawling on the ground, against his will, he is obliged to perform the duty of the rain king. And, if at the Dionysian cults, human sacrifice and flagellation were part of the rituals, Henderson too has to strike and be struck by the whips, for "caught up in this madness, I fended off blows from my position on my kness, for it seemed to me that I was fighting for my life, and I yelled", enacting out again Dionysus' sufferings and death as he lies prostrated during the ceremony, crying "Thy will be done! Not my will, but Thy will!".

This madness to wich Henderson refers, this swooning or "intoxication" already mentioned as belonging to the Dionysiac state, as the product of lormative forces arising directly from nature and so masterfully described in Nietzsche's "Dionysos and Apollo"," is in the same spirit as carnivalistic lestivities: the participants live carnival, and man's behavior, gesture and word are liberated in this life "drawn out of its usual rut", for "the hicrarchical system and all the connected forns of fear, awe, piety, etiquette" 12 are suspended, in an oxymoronic combination of sacred and profane, high and low, birth and death. Thus, the ceremonies in honor of Dionysus and of the Sungo are brought into touch through their common carnivalistic aspects, with Henderson, as rain-king, moving through his feat of lifting the cloud goddess from a slave to a god-like position, only to suffer again flagellation, death and rebirth during the rain ceremony. It is this same god, Dionysus, who suffers and resurrects, who relinquishes life and then is born again, that

il Nictssche, F. "Dionysus und Apollo". In: Ellmann, R. \& Feidelson, C.. cds. The Mockern Tradition. New York: Oxford Univ. Press, 1965. p. 550: the clovest analogy to apprehend the essence of Dionysiac rapture is fumished by "physical intoxication. Dionysiac stirrings arise either through the influence of thase narcotic potions of which all primitive races speak in their hymns, or through the powerful approach of spring, which penctrates with joy the whole frame of nature. So stirred, the individual forgets himself completely. (...) Not only docs the bond hetween man and man eome lo be forged once more hy the magic of the Dionysiac rite, hut nature itself, long alienated or subjugated, rises again to celebrate the reconciliation with her prodigal son, man. (...) Now the slave emerges as a free man; all the rigid. hostile walls which either necessity or despotism has erected between men are shattered (...) Man now expresses himsell through song and dance (...). Each of his gestures betokens enchantment; (...) He feels himself to he godlike and strides with the same elation and ecstasy as the gods he has seen in his dreams. No longer the artist, he has himself hecome a work of art".

I2 Bakhtin, M. p. I0I. 
became a symbol of everlasting life - no longer the rustic god of wine and jollity, not even the god of orgiastic delirium.

In this manner, after this general purgation through whipping, chanting and dancing, in which the gods are disparaged, a thunderclap is heard. Finally the clouds open and rain ${ }^{3}$ begins to fall, covering the whole orgiastic scene with silver bubbles - which, in contrast to the octopus's bubbles, symbolize rebirth - while the amazons embrace Henderson with their now wet bodies. A real deluge follows, purifying the air and the frenzied bodies. The great crowning has ended, Dahfu returns to his palace and Henderson is left standing in his "coat of earth, like a giant turnip", with what is left over from his green costume of Sungo, naked. He has been divested of his comic rain-king attire, as befits dethroning, in which "the regal vestments are stripped from the discrownee, his crown is taken off, the remaining symbols of authority are removed, and he is ridiculed and beaten". ${ }^{4}$ But the comicality of his looking like a "giant tumip" - the hero who has lifted Mummah - is further enhanced by the concern he displays with his helenel, after the ordeal was over and rain was pouring down. As he tells his guide,

"Romilayu," (...) "please, man you ve gex to help me. Lowk at the condition I'm in. Find my clothes. Where is the king"? Where are they all:? Pick up my clothes - my helmet," (...) "l"ve gol wo have my helmet."

as if his helmet - another crown - could be a substitute for his lost rain-king outlit or cover up his nakedness.

The regenerating powers of rain have thus finally extinguished, together with Henderson s positive exertion in having lifted Mummah, the malevolent fire that bumed inside him, as part of the ordeal he has to pass through, in order to ohtain truth. And, although Henderson s adventures in Africa are by no means over for other more dangerous experiences lie ahead, still a turning point has been reached, for the hero has at last managed to test his physical prowess and thus become, malgre lui, the Sungo.

19. Steig. M. Stresses that "Henderson's African experiences, including the rain-making. teach him that there are relatioms ameng man s hady. spirit and the metaphysical univene which are heyond the limits of rationalistic theught". "Bellow.s Henderson and the Limits of Freudian Crilicism". Paunch (36-37): 4 . April 1973.

is Bathtin. A. p. 103. 


\section{SUMMARY}

This aricle deals with the climactic scene of Bellow's novel Henderson the Rain King, in which the hero is crowned and subsequently discrowned as the Sungo, or Rain King of the Wariri. The whole scene is imbued with camivalistic categories, rituals and images, as discussed by Bakhtin in Problems of Dostoevsky's Poetics, thus making ambiguous any monological interpretation of the episodes.

\section{RESUMO}

Este trabalho discute a cena culminante do romance Henderson the Rain King, de Saul Bellow, na qual o heroi é coroado e em seguida descoroado como Sungo, ou Rei da Chuva dos Wariri. A cena inteira está impregnada de categorias, rituais e imagens camavalescos, como apresentados por Bakhtin em Problems of Dostoevsky's Poetics, ambigüizando desta maneira qualquer interpretação monológica dos eventos.

\section{BIBLIGRAPHICAL REFERENCES}

BACHELARD, G. La Terre et les Rêveries de la Volonté. Paris; J.Corti, 1971.

BAKHTIN, M. Problems of Dostoevsky's Poetics. Ann Arbor: Ardis, 1973.

BELLOW, S. Henderson the Rain King. New York: Fawcelt, 1959.

. The Adventures of Augie March. New York: Viking. 1969.

FRAZER, G.G. The Golden Bough. London; Macmillan, 1974.

NIETZSCHE, F. "Dionysus and Apollo". In: Ellmann, R. \& Feidelson, C. eds. The Modern Tradition. New York: Oxford Univ. Press, 1965.

ROHDE, E. Psyche. Leipzig: Kröner, 1893.

STEIG, M. "Bellow's Henderson and the Limits of Freudian Criticism". Paunch n.36-37, p.39-46, april 1973.

SYPHER, W. "The Meanings of Comedy". In: Comedy. New York: Doubleday, 1956. 